\title{
Evaluasi Konsumsi Protein dan Energi terhadap Produksi Susu Sapi Perah Awal Laktasi
}

\section{Evaluation of Protein and Energy Intakes to Milk Production in the Early Lactation Cows}

\author{
D. S. Adi, D. W. Harjanti*, dan R. Hartanto \\ Departemen Peternakan, Fakultas Peternakan dan Pertanian, Universitas Diponegoro, 50275 - Indonesia \\ *Corresponding E-mail: harjantidian@gmail.com \\ (Diterima: 7 Juli 2020; Disetujui: 2 Oktober 2020)
}

\begin{abstract}
ABSTRAK
Penelitian bertujuan untuk mengevaluasi hubungan konsumsi protein dan energi terhadap bobot badan kering kandang dan laktasi serta produksi susu di bulan pertama awal laktasi. Materi yang digunakan adalah 24 ekor induk sapi perah peranakan FH bunting 8 bulan sampai 1 bulan setelah melahirkan. Penelitian dilakukan secara observasional dan penentuan sampel dilakukan dengan cara purposive sampling. Variabel yang diamati yaitu bobot badan, konsumsi protein kasar (PK) dan total digistibel nutrient (TDN) setiap minggu serta produksi susu awal laktasi bulan pertama. Data penelitian evaluasi ketercukupan PK dan TDN dianalisis secara deskriptif, sedangkan data hubungan PK dan TDN terhadap bobot badan dan produksi susu dianalisis menggunakan korelasi Rank Spearman dan regresi linier sederhana. Hasil penelitian menunjukan bahwa konsumsi PK ternak tidak berkorelasi dengan bobot badan sebelum partus $(\mathrm{P}=0,315)$. Konsumsi TDN dan bobot badan sebelum partus berkorelasi positif moderat $(\mathrm{R}=0,598)$. Konsumsi PK setelah partus berkorelasi positiflemah $(\mathrm{R}=0,386)$ dengan bobot. Konsumsi TDN setelah partus berkorelasi positif moderat $(\mathrm{R}=0,674)$ terhadap bobot. Konsumsi PK setelah partus berkorelasi positif lemah $(\mathrm{R}=0,362)$ dengan produksi susu. konsumsi TDN setelah partus berkorelasi positif moderat $(\mathrm{R}=0,552)$ terhadap produksi susu. Simpulan dari penelitian ini adalah konsumsi PK dan TDN memiliki hubungan positif dengan bobot badan dan produksi susu saat masa awal laktasi.
\end{abstract}

Kata kunci: protein, energi, produksi susu, bobot badan, kering kandang

\section{ABSTRACT}

The research aimed to evaluate the relationship between protein and energy intakes to dry period bodyweight, lactation body weight, and milk production in early lactation. The material used in this study was 24 FH dairy cows eight months to 1 month after parturition. This research method is observational research, and the determination of the sample uses a purposive sampling method. The observed variables are body weights, crude protein (CP), and total digestible nutrient (TDN) consumptions every week and milk productions in the first month of lactations. Adequacy PK and TDN intakes data were analyzed by descriptive method. In contrast, the relationship between PK and TDN intakes to body weight and milk production data were analyzed by Rank Spearman correlations and simple linear regression. The results showed that $P K$ intakes didn't correlate with bodyweight before parturition $(P=0.315)$. TDN intakes and body weight before parturition were positively correlated moderately $(R=0.598)$. PK intakes after parturition were weakly positively correlated $(R=0.386)$ with body weight. TDN intakes after parturition have a moderate positive correlation $(R=0.674)$ to body weight. PK intakes after parturition were positively weakly correlated $(R=0.362)$ with milk production. TDN intakes after parturition have a moderate positive correlation $(R=0.552)$ on milk production. The conclusion from this research is protein and energy intake has a positive relationship with body weight and milk production during the initial lactation period.

Keywords: protein, energy, milk productions, body weight, dry period 


\section{PENDAHULUAN}

Sapi perah adalah sapi yang diternakkan untuk menghasilkan susu guna mencukupi kebutuhan asupan nutrisi manusia (Haloho et al., 2013). Sapi di Indonesia pada umumnya dapat memproduksi susu 2,4003,000 liter/ekor/laktasi (Nugraha et al., 2016). Masa laktasi sapi perah dibagi menjadi 3 fase yaitu awal, pertengahan dan akhir laktasi serta kemudian sapi dikering kandangkan untuk menyiapkan masa laktasi berikutnya (Moran, 2005). Produksi susu awal laktasi dipengaruhi oleh pakan yang dikonsumsi, karena pakan merupakan faktor dari jumlah produksi susu yang dihasilkan (Rusdiana dan Sejati, 2009). Sapi pada masa laktasi awal akan mengalami beberapa perubahan fisik seperti penurunan bobot badan paska melahirkan yang disebabkan oleh pembongkaran cadangan makanan untuk memenuhi produksi susu dan mulai mengalami kenaikan produksi susu (Tasse dan Auza, 2014).

Masa kering kandang adalah salah satu faktor yang dapat mempengaruhi produksi susu dimasa laktasi berikutnya. Sapi dikering kandangkan dengan tujuan mengembalikan stamina tubuh induk untuk mempersiapkan kelahiran pedet dalam bentuk bobot badan dan untuk mempersiapkan produksi susu setelah lahir (Nugroho et al., 2015). Salah satu faktor yang harus diperhatikan saat sapi di kering kandangkan adalah kandungan pakan dan jumlah pakan yang diberikan. Pakan yang diberikan harus sesuai dengan kebutuhan ternak. Kebutuhan sapi kering kandang dipengaruhi oleh kebutuhan pokok dan aktivitas ternak. Kandungan yang diperlukan ternak dalam pakan antara lain adalah sumber serat kasar dari hijauan, sumber energi, protein, lemak, vitamin, mineral dan kalsium (Astuti et al., 2009). Kebutuhan nutrisi sapi kering kandang dengan bobot $500 \mathrm{~kg}$ yaitu bahan kering (BK) sebesar 10,1 kg, total digestible nutrient (TDN) sebanyak 4,90 kg/ hari dan protein sekitar $978 \mathrm{~g}$ (NRC, 2001). Jika kebutuhan nutrisi sapi kering kandang tidak tercukupi dari jumlah konsumsi pakan maka akan terjadi beberapa efek seperti bobot badan induk tidak optimal untuk melahirkan (Staric dan Zadnik, 2010).

Kebutuhan nutrisi sapi perah awal laktasi dipengaruhi oleh kebutuhan pokok dan produksi susu. Kebutuhan hidup pokok pada sapi perah ditentukan oleh berat badan, kesehatan dan aktivitas ternak, sedangkan kebutuhan untuk produksi susu dipengaruhi oleh produksi dan kadar lemak susu (Bath et al., 1985). Kebutuhan nutrisi sapi perah awal laktasi harus tercukupi dengan konsumsi pakan yang dapat dilihat dalam jumlah bahan kering pakan. BK pakan mengandung beberapa nutrisi seperti lemak, protein, kalsium, fosfor, vitamin dan energi pakan yang dapat dikur dalam total digestible nutrient (TDN) (Bilal et al., 2016). Protein dan TDN pakan dapat mempengaruhi produksi dan kualitas susu yang akan dihasilkan, sehingga apabila asupan nutrisi yang belum cukup untuk proses sintesis susu akan merombak cadangan makanan dalam tubuh hingga menyebabkan penurunan bobot badan (Abdillah et al., 2015). Jika kebutuhan nutrisi sapi laktasi tidak tercukupi dari jumlah konsumsi pakan maka akan membuat produksi susu sapi awal laktasi menjadi kurang optimal (Staric dan Zadnik, 2010).

Salah satu cara untuk mengoptimalkan produksi susu adalah dengan memenuhi kebutuhan nutrisi ternak khususnya TDN dan protein pada masa kering kandang dan awal laktasi. Penelitian ini dilakukan dengan tujuan untuk mengevaluasi hubungan konsumsi protein dan energi terhadap produksi susu di bulan pertama awal laktasi. Serta manfaat dari penelitian ini yaitu untuk memberikan informasi tentang pengaruh konsumsi protein dan energi induk kering kandang hingga laktasi bulan pertama terhadap produksi susu awal laktasi. Hipotesis penelitian ini yaitu adanya korelasi yang nyata antara konsumsi protein dan TDN terhadap produksi susu awal laktasi.

\section{METODE}

\section{Tempat Penelitian}


Penelitian ini dilaksanakan di di CV. Capita Farm, Kecamatan Getasan dan KTT Rias, Kecamatan Kopeng, Kabupaten Semarang, Jawa Tengah. Analisis proksimat pakan hijauan dan konsentrat dilakukan di Laboratorium Ilmu Nutrisi dan Pakan, Fakultas Peternakan dan Pertanian, Universitas Diponegoro, Semarang.

\section{Materi Penelitian}

Materi yang digunakan dalam penelitian ini adalah 24 ekor induk sapi perah peranakan FH bunting 8 bulan. Alat yang digunakan yaitu 4 buah pita ukur dengan panjang $150 \mathrm{~cm}$ yang digunakan sebagai alat mengukur lingkar dada induk sapi perah untuk melakukan pendugaan bobot badan karena di Kelompok Tani Ternak tidak tersedia timbangan bobot badan, timbangan gantung untuk menimbang pemberian dan sisa pakan, karung sebagai wadah penimbangan pakan, gelas ukur untuk mengukur jumlah produksi susu dan jumlah sampel susu yang akan diambil, lactoscan untuk analisis berat jenis susu, plastik klip dan cooling box sebagai wadah sampel susu.

\section{Metode}

Penelitian ini merupakan penelitian observasional dan mempunyai tiga tahap penelitian antara lain yaitu tahap pra penelitian, pengambilan data dan pengolahan data.

\section{Tahap Pra-Penelitian}

Tahap persiapan pengambilan data dilakukan dengan cara melakukan survey dan melakukan pendataan sapi kering kandang yang akan melahirkan di daerah Kabupaten Semarang dan sekitarnya yaitu CV. Capita Farm, Kecamatan Getasan dan KTT Rias, Kecamatan Kopeng, Kabupaten Semarang dan penentuan sampel dilakukan dengan cara purposive sampling.

\section{Tahap Pengambilan Data}

Pengumpulan data primer sebelum partus berupa data bobot badan, konsumsi protein dan TDN selama 2 minggu sebelum partus, sedangkan data primer setelah partus yaitu bobot badan, konsumsi protein dan TDN serta produksi susu dan berat jenis susu selama 4 minggu setelah partus. Data bobot badan diambil 1 kali setiap minggu dengan cara melakukaan pendugaan bobot badan yaitu mengukur lingkar dada menggunakan pita ukur dan dihitung menggunakan rumus schrool. Data konsumsi BK diperoleh dengan cara menghitung jumlah pemberian pakan dikurangi jumlah sisa pakan, 1 kali setiap 1 minggu. Data konsumsi PK diperoleh dengan cara konsumsi pakan BK dikalikan dengan kadar PK pakan, sedangkan konsumsi TDN diperoleh dengan cara konsumsi pakan BK dikalikan dengan kadar TDN pakan. Data produksi susu diperoleh dengan cara mengukur produksi susu tiap sapi setiap hari. Data berat jenis susu diperoleh dengan menggunakan laktoscan tiap sapi setiap minggu. Data kandungan pakan dilakukan dengan cara mengambil sampel pakan pada awal, pertengahan dan akhir penelitian sebanyak masing-masing $500 \mathrm{~g}$, di kering udarakan dan menimbang berat kering udara kemudian dicampur dan dianalisis proksimat (Tabel 1). CV. Capita Farm menggunakan hijauan rumput gajah dan tebon jagung yang dicampur secara merata dan konsentrat yang buat dengan komposisi yang sama secara terus menerus, sedangkan pakan yang digunakan KTT Rias adalah hijauan berupa rumput gajah dan konsentrat dengan merek Calfeed.

Perhitungan Parameter Penelitian :

Bobot Badan $=\frac{(\text { Lingkar Dada }+22)^{2}}{100}$

(Rumus schrool)

Konsumsi PK $=($ BK Pemberian $\times \%$ PK $)-$ (BK sisa $\times \%$ PK Sisa)

Konsumsi TDN $=($ BK Pemberian $\times \%$ TDN $)$ $-($ BK sisa $\times \%$ TDN Sisa $)$

Produksi susu $(\mathrm{kg})=$ produksi susu $(\mathrm{l}) \times$ berat jenis $(\mathrm{kg} / \mathrm{l})$

\section{Tahap Pengolahan Data}

Data penelitian evaluasi ketercukupan PK dan TDN dianalisis secara deskriptif, sedangkandatahubunganPKdanTDNterhadap bobot badan dan produksi susu dianalisis menggunakan korelasi Rank Spearman $(\rho=$ rho $)$ dan regresi linier sederhana untuk 
Tabel 1. Hasil Analisis Proksimat Pakan

\begin{tabular}{|c|c|c|c|c|c|c|c|c|}
\hline No & Bahan Pakan & $\begin{array}{l}\mathrm{BK} \\
(\%)^{*}\end{array}$ & $\begin{array}{l}\mathrm{Abu} \\
(\%)^{*}\end{array}$ & $\begin{array}{c}\text { SK } \\
(\%)^{*}\end{array}$ & $\begin{array}{l}\text { LK } \\
(\%)^{*}\end{array}$ & $\begin{array}{l}\text { PK } \\
(\%)^{*}\end{array}$ & $\begin{array}{l}\text { BETN } \\
(\%)^{* *}\end{array}$ & $\begin{array}{c}\mathrm{TDN} \\
(\%)^{* * *}\end{array}$ \\
\hline 1 & $\begin{array}{l}\text { Hijauan CV. Capita } \\
\text { Farm }\end{array}$ & 25,48 & 12,89 & 36,61 & 2,02 & 8,14 & 40,34 & $50,89^{1}$ \\
\hline 2 & $\begin{array}{l}\text { Konsentrat CV. Capita } \\
\text { Farm }\end{array}$ & 89,94 & 7,20 & 20,44 & 6,63 & 16,63 & 49,10 & $67,53^{2}$ \\
\hline 3 & $\begin{array}{l}\text { Sisa Pakan CV. Capita } \\
\text { Farm }\end{array}$ & 25,58 & 15,84 & 37,84 & 1,74 & 8,73 & 35,85 & $49,41^{1}$ \\
\hline 4 & Hijauan KTT Rias & 27,29 & 14,47 & 42,34 & 1,77 & 10,50 & 30,92 & $46,00^{1}$ \\
\hline 5 & Konsentrat KTT Rias & 89,11 & 16,05 & 23,95 & 4,00 & 18,35 & 37,65 & $54,62^{2}$ \\
\hline
\end{tabular}

Keterangan:

* Hasil Analisis Laboratorium Ilmu Nutrisi Pakan, Fakultas Peternakan dan Pertanian, Universitas Diponegoro.

** BETN dihitung dengan rumus:

BETN $(\%)=100-(\mathrm{Abu}+\mathrm{PK}+\mathrm{LK}+\mathrm{SK})$

***Menurut Rumus Sutardi (2001) yaitu :

${ }^{1}$ TDN $\%=70,6+0,259 \% \mathrm{PK}+1,01 \% \mathrm{LK}-0,76 \% \mathrm{SK}+0,0991 \% \mathrm{BETN}$

${ }^{2}$ TDN $\%=2,79+1,17 \%$ PK $+1,74 \%$ LK- $0,295 \%$ SK $+0,810 \%$ BETN

mengetahui korelasi antara konsumsi protein dan energi terhadap bobot badan sebelum dan sesudah partus, konsumsi protein dan energi terhadap produksi susu. Rumus korelasi Rank Spearman $(\rho=$ rho $)$ sebagai berikut :

Keterangan:

$$
\rho=1-\frac{6 \sum d_{i}^{2}}{n\left(n^{2}-1\right)}
$$

$\rho=$ Koefisien korelasi Rank Spearman $(\rho=$ rho)

$\mathrm{d}_{\mathrm{i}}=$ Selisih ranking antara variabel konsumsi protein dan energi $(\mathrm{X})$ dan produksi susu (Y)

$\mathrm{n}=$ Jumlah pasangan Rank Spearman untuk $(5<\mathrm{n}<30)$

$1 / 6=$ Angka konstan

Hipotesis:

$\mathrm{H} 0$ = Tidak ada hubungan antara konsumsi protein dan energi terhadap bobot badan dan produksi susu awal laktasi.

$\mathrm{H1}=$ Terdapat hubungan antara konsumsi protein dan energi terhadap bobot badan dan produksi susu awal laktasi
Kriteria pengujian:

$\rho$ hitung $>\rho$ tabel $=\mathrm{H} 0$ ditolak dan $\mathrm{H} 1$ diterima $\rho$ hitung $<\rho$ tabel $=\mathrm{H} 0$ diterima dan $\mathrm{H} 1$ ditolak

\section{Kriteria Hubungan}

\begin{tabular}{ll}
\hline r & Kriteria Hubungan \\
\hline$(-1)$ & Negatif Sempurna \\
$(-1)-(-0,9)$ & Negatif Kuat \\
$(-0,9)-(-0,5)$ & Negatif Moderat \\
$(-0,5)-0$ & Negatif Lemah \\
0 & Tidak Berkorelasi \\
$0-0,5$ & Positif Lemah \\
$0,5-0,9$ & Positif Moderat \\
$0,9-1$ & Positif Kuat \\
1 & Positif Sempurna \\
\hline
\end{tabular}

Sumber: Sudarno, 2017. berikut:

Rumus regresi linier sederhana sebagai

$$
\mathrm{Y}=\mathrm{a}+\mathrm{bX}
$$

Keterangan:

$\mathrm{Y}=$ Variabel terikat (bobot badan dan produksi susu)

$\mathrm{X}=$ Variabel bebas (konsumsi PK dan TDN)

$\mathrm{a}=$ Intersep 
$\mathrm{b}=$ Koefiesien regresi

Hipotesis:

$\mathrm{H} 0=$ Tidak terdapat hubungan linier yang signifikan antara konsumsi protein dan energi terhadap bobot badan dan produksi susu awal laktasi.

$\mathrm{H} 1$ = Terdapat hubungan linier yang signifikan antara konsumsi protein dan energi terhadap bobot badan Kriteria pengujian: dan produksi susu awal laktasi.

$\mathrm{r}$ hitung $\geq \mathrm{r}$ tabel $=\mathrm{H} 0$ ditolak dan $\mathrm{H} 1$ diterima $\mathrm{r}$ hitung $<\mathrm{r}$ tabel $=\mathrm{H} 0$ diterima dan $\mathrm{H} 1$ ditolak

\section{HASIL DAN PEMBAHASAN}

\section{Evaluasi Ketercukupan PK dan TDN}

Hasil penelitian tentang evaluasi ketercukupan Protein Kasar (PK) dan total digestible nutrient (TDN) sapi perah kering kandang dan laktasi bulan pertama dapat dilihat bahwa rata-rata produksi susu minggu 1 - 3 setelah partus $(17,17$ - 19,17 1/ekor/ hari) meningkat dan pada minggu ke 4 ratarata produksi (18,75 1/ekor/hari) menurun Produksi susu sudah baik karena lebih dari 10 1/ekor/hari sedangkan kebutuhan protein dan TDN belum mencukupi (Tabel 2). Hal ini terjadi karena kekurangan tersebut dapat dipenuhi dari perombakan cadangan makanan dalam tubuh. Kebuntingan sapi memiliki cadangan tubuh yang cukup saat awal laktasi yang ditandai dengan bobot badan akhir yang baik dengan BCS sekitar 3,5 dan evaluasi PK dan TDN yang positif atau berlebih. Menurut Nugraha et al. (2016) sapi di Indonesia dapat menghasilkan $8-10$ liter susu/hari atau 2,400-3,000 liter/ekor/laktasi. Menurut Santosa et al. (2014) produksi susu di masa awal laktasi dipengaruhi oleh beberapa faktor antara lain kandungan pakan, bobot ternak dan tatalaksana pemeliharaan. Selain itu produktivitas sapi perah sendiri dipengaruhi oleh faktor lain seperti frekuensi pemerahan, periode laktasi, kesehatan ternak, air minum, interval pemerahan susu dan kesehatan sapi perah tata laksana pemberian pakan dan kandungan nutrien pakan. Produksi susu yang baik dan kurangnya ketercukupan nutrien ini diikuti dengan penurunan bobot badan. Menurut Abdillah et al. (2015) apabila asupan nutrien awal laktasi belum cukup untuk proses sintesis susu, maka akan merombak cadangan makanan dalam tubuh yang sudah ditimbun pada saat masa kering kandang sehingga menyebabkan penurunan bobot badan.

Berdasarkan Gambar 1, terlihat bahwa bobot badan pada minggu 2 dan 1 sebelum partus meningkat kemudian pada minggu $1-3$ setelah partus bobot badan menurun dan pada minggu ke 4 meningkat kembali. Hal ini sesuai dengan Moran (2005) yang menggambarkan bahwa bobot badan sebelum partus akan naik, kemudian setelah partus akan turun dan kemudian akan kembali naik. Menurut

Tabel 2. Evaluasi Ketercukupan PK dan TDN

\begin{tabular}{|c|c|c|c|c|c|c|c|c|c|}
\hline \multirow{2}{*}{ Minggu } & \multirow{2}{*}{$\begin{array}{c}\text { Prod. } \\
\text { Susu } \\
(\mathrm{kg})\end{array}$} & \multirow{2}{*}{$\begin{array}{c}\text { Lingkar } \\
\text { Dada } \\
(\mathrm{cm}) \\
\end{array}$} & \multirow{2}{*}{$\begin{array}{c}\text { Bobot } \\
\text { Badan } \\
(\mathrm{kg})\end{array}$} & \multicolumn{3}{|c|}{ PK $(\mathrm{kg})$} & \multicolumn{3}{|c|}{ TDN (kg) } \\
\hline & & & & Keb & Kon & Eval & Keb & Kon & Eval \\
\hline 2 Minggu SbP & - & 196,42 & 478,46 & 0,92 & 1,59 & $+0,69$ & 4,70 & 6,90 & 2,20 \\
\hline $1 \mathrm{Minggu} \mathrm{SbP}$ & - & 198,79 & 488,82 & 0,97 & 1,69 & $+0,73$ & 4,70 & 9,59 & 4,88 \\
\hline 1 Minggu StP & 17,17 & 193,04 & 463,97 & 2,15 & 2,07 & $-0,08$ & 10,04 & 8,71 & $-1,33$ \\
\hline 2 Minggu StP & 18,65 & 190,04 & 451,16 & 2,28 & 2,04 & $-0,25$ & 10,37 & 8,52 & $-1,85$ \\
\hline 3 Minggu StP & 19,17 & 187,46 & 439,98 & 2,31 & 2,06 & $-0,25$ & 10,50 & 8,54 & $-1,96$ \\
\hline 4 Minggu StP & 18,75 & 187,71 & 441,15 & 2,33 & 2,01 & $-0,31$ & 10,58 & 8,46 & $-2,12$ \\
\hline
\end{tabular}

Keterangan: Keb = Kebutuhan, Kon = Konsumsi, Eval = Evaluasi Ketercukupan, SbP = Sebelum Partus, $\mathrm{StP}=$ Setelah Partus 


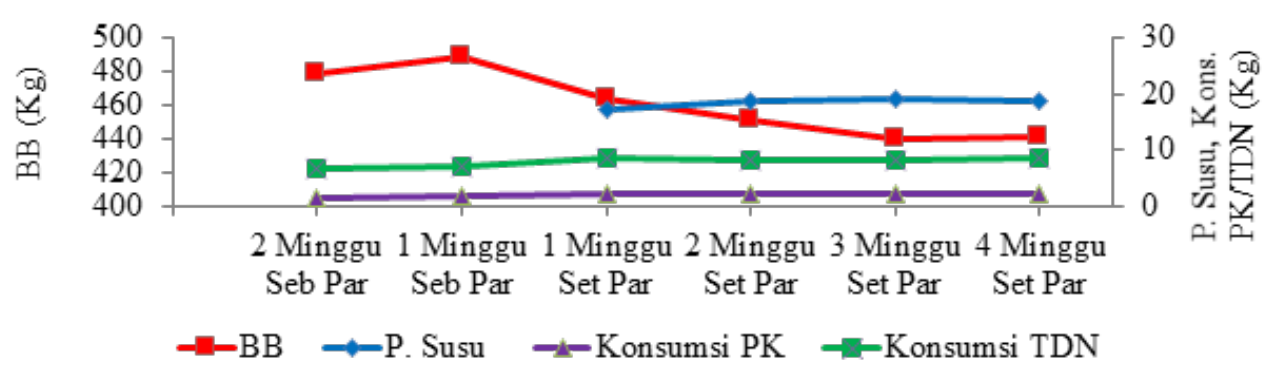

Gambar 1. Bobot badan, Produksi Susu, Konsumsi PK, dan TDN Sapi

Tabel 3. Uji Regresi Konsumsi PK Terhadap Bobot Badan Sebelum Partus

\begin{tabular}{lccccc}
\hline Minggu & $\mathrm{n}$ & Persamaan Regresi & $\mathrm{r}$ & $\mathrm{R}^{2}$ & P Value \\
\hline 2 Minggu Seb Par & 24 & $\mathrm{Y}=437,246+25,568 \mathrm{X}$ & 0,158 & 0,025 & 0,460 \\
1 Minggu Seb Par & 24 & $\mathrm{Y}=460,901+16,477 \mathrm{X}$ & 0,121 & 0,015 & 0,574 \\
\hline Total Seb Par & 48 & $\mathrm{Y}=447,588+21,808 \mathrm{X}$ & 0,148 & 0,022 & 0,315 \\
\hline
\end{tabular}

Keterangan: Seb Par $=$ Sebelum Partus, $r=$ Koefisien Korelasi, $\mathrm{R}^{2}=$ Koefisien Determinasi

Astuti et al. (2010) bobot sapi perah yang sedang bunting sebaiknya lebih dari $400 \mathrm{~kg}$ dengan BCS 3 - 4. Menurut Abdillah dan Surjowardojo (2018) bobot sapi perah dapat mempengaruhi produksi susu awal laktasi dan mempengaruhi kebutuhan nutrien sapi. Menurut Tasse dan Auza (2014) semakin besar bobot badan induk dan ambing maka dapat menghasilkan susu yang banyak pula. Hal ini sesuai dengan pendapat Nur et al. (2015) yang menyatakan bahwa sapi dengan bobot badan tinggi dapat menyimpan cadangan makanan yang lebih banyak yang akan diolah menjadi susu serta sapi dengan bobot badan tinggi memiliki ambing dengan volume yang besar pula sehingga dapat menampung dan memproduksi susu lebih banyak.

Evaluasi ketercukupan PK dan TDN pada minggu ke 2 dan 1 sebelum partus konsumsi melebihi kebutuhan namun pada minggu $1-4$ setelah partus konsumsi kurang dari kebutuhan. Menurut data penelitian yang diambil kebutuhan pakan sapi awal laktasi akan naik karena selain digunakan sebagai kebutuhan pokok juga untuk produksi susu awal laktasi, namun sapi awal laktasi mengalami penurunan nafsu makan sehingga bobot badan berkurang karena cadangan makanan dibongkar untuk memenuhi kebutuhan hidup. Kebutuhan PK dan TDN sapi kering kandang digunakan untuk menyiapkan kelahiran. Menurut Fillian et al. (2016) konsumsi protein dan energi pada sapi kering kandang akan dialokasikan untuk beraktivitas, kebutuhan pokok sapi serta pembentukan fetus pedet sehingga bobot badan sapi kering kandang meningkat. Kebutuhan sapi awal laktasi digunakan untuk hidup pokok dan produksi susu sehingga kebutuhan protein dan energi meningkat dibanding dengan saat kering kandang. Evaluasi ketercukupan PK dan TDN dapat dilihat dari jumlah kebutuhan ternak dibandingkan dengan jumlah pakan yang dikonsumsi. Menurut Bath et al. (1985) kebutuhan energi pada sapi perah laktasi ditentukan oleh kebutuhan untuk hidup pokok yang dipengaruhi oleh berat badan, kesehatan dan aktivitas ternak, sedangkan kebutuhan untuk produksi susu dipengaruhi oleh jumlah produksi susu yang dihasilkan dan banyaknya kadar lemak susu.

Kebutuhan sapi awal laktasi yang lebih banyak membuat ternak harus membongkar cadangan makanan untuk memenuhi kebutuhan pokok dan produksi susu, sehingga bobot badan menurun. Hal ini terlihat pada evalasi setelah partus yang menunjukan 
Tabel 4. Uji Regresi Konsumsi TDN Terhadap Bobot Badan Sebelum Partus

\begin{tabular}{lccccc}
\hline Minggu & $\mathrm{n}$ & Persamaan Regresi & $\mathrm{r}$ & $\mathrm{R}^{2}$ & P Value \\
\hline 2 Minggu Seb Par & 24 & $\mathrm{Y}=3,429+0,022 \mathrm{X}$ & 0,651 & 0,423 & 0,001 \\
1 Minggu Seb Par & 24 & $\mathrm{Y}=3,608+0,022 \mathrm{X}$ & 0,657 & 0,406 & 0,000 \\
\hline Total Seb Par & 48 & $\mathrm{Y}=3,559+0,022 \mathrm{X}$ & 0,657 & 0,432 & 0,000 \\
\hline
\end{tabular}

Keterangan: Seb Par $=$ Sebelum Partus, $r=$ Koefisien Korelasi, $\mathrm{R}^{2}=$ Koefisien Determinasi

produksi susu yang perlahan meningkat dan bobot badan perlahan menurun. Manajemen pemberian pakan yang tepat dapat mempengaruhi ketercukupan nutrien yang dibutuhkan sehingga dapat menghasilkan produktivitas sapi perah menjadi maksimal. Menurut Laryska dan Nurhajati (2013) pemberian pakan sapi perah harus sesuai dengan kebutuhan dan tidak berlebihan agar pakan tetap efisien dan kebutuhan untuk produksi dapat tercukupi.

\section{Hubungan Konsumsi Protein Terhadap Bobot Badan Sebelum Partus}

Hubungan konsumsi protein kasar terhadap bobot badan 2 minggu sebelum partus terlihat bahwa konsumsi PK pada 2 minggu, 1 minggu dan total 2 minggu sebelum partus tidak berkorelasi terhadap bobot badan sapi perah $(\mathrm{P}>0,05)$ (Tabel 3). Hal ini terjadi karena konsumsi protein minggu 2 dan 1 sebelum partus dari semua sapi sudah mencukupi kebutuhan: konsumsi rata-rata sebesar 1,61 kg dan 1,67 kg/hari, sedangkan kebutuhan protein sebesar $0,92 \mathrm{~kg} /$ hari dan $0,97 \mathrm{~kg}$ /hari. Kebutuhan PK yang tercukupi bahkan melebihi ini menyebabkan bobot badan saat kering kandang dapat optimal yang dicerminkan dengan BCS (body condition score) sapi di akhir kebuntingan sebesar 3-4.

Walaupun konsumsi protein ternak tidak berkorelasi nyata secara langsung dengan bobot badan sebelum partus namun sebenarnya konsumsi protein dialokasikan untuk kebutuhan pokok ternak dan pertumbuhan jaringan tubuh ternak serta janinnya, kemudian apabila konsumsi sudah mencukupi akan diubah menjadi cadangan makanan dan apabila berlebih akan dibuang bersama feses. Menurut Waldi et al. (2017), konsumsi protein ternak harus selaras dengan kebutuhan ternak, protein digunakan untuk membantu mikroba mensintesis protein mikroba dalam rumen sehingga jumlah mikroba semakin banyak dan dapat mengoptimalkan penyerapan pakan. Syafri et al. (2014) menyatakan bahwa protein yang dikonsumsi akan di hidrolisis dalam rumen menjadi peptida kemudian menjadi asam amino yang akan diubah menjadi amonia dan apabila berlebih akan dibuang bersama urin dan feses.

\section{Hubungan Konsumsi TDN Terhadap Bobot Badan Sebelum Partus}

Hubungan konsumsi total digestible nutrient (TDN) terhadap bobot badan 2 minggu sebelum partus terlihat bahwa konsumsi TDN pada 2 minggu, 1 minggu dan total 2 minggu sebelum partus berkorelasi terhadap bobot badan $(\mathrm{P}<0,05)$ (Tabel 4). Hubungan konsumsi TDN dan bobot badan sebelum partus mempunyai tingkat korelasi positif moderat $(r=0,598)$ yang artinya peningkatan konsumsi TDN akan diikuti oleh peningkatan bobot badan. Hubungan tersebut dalam persamaan regresi $Y=3,559+0,022 X\left(R^{2}=0,432\right)$ dan $(\mathrm{P}=0,000)$ yang artinya $43,2 \%$ variabel $\mathrm{Y}$ (bobot badan) dapat dijelaskan oleh variabel $\mathrm{X}$ (konsumsi TDN). Konsumsi TDN minggu 2 dan 1 sebelum partus rata-rata sebesar 6,70 $\mathrm{kg}$ dan 7,02 kg/hari. Konsumsi TDN minggu 2 dan 1 sudah mencukupi kebutuhan TDN sebesar 4,70 kg/hari dan 4,79 kg/hari.

Konsumsi TDN pada 2 dan 1 minggu sebelum partus sudah mencukupi kebutuhan ternak. Konsumsi TDN digunakan sebagai cadangan energi dalam bentuk bobot badan, sehingga konsumsi yang sudah mencukupi 
Tabel 5. Uji Regeresi Konsumsi PK Terhadap Bobot Badan Setelah Partus

\begin{tabular}{lccccc}
\hline Minggu & $\mathrm{n}$ & Persamaan Regresi & $\mathrm{r}$ & $\mathrm{R}^{2}$ & P Value \\
\hline 1 Minggu Set Par & 24 & $\mathrm{Y}=331,081+64,135 \mathrm{X}$ & 0,445 & 0,198 & 0,209 \\
2 Minggu Set Par & 24 & $\mathrm{Y}=351,294+49,036 \mathrm{X}$ & 0,335 & 0,113 & 0,109 \\
3 Minggu Set Par & 24 & $\mathrm{Y}=321,705+57,406 \mathrm{X}$ & 0,395 & 0,156 & 0,056 \\
4 Minggu Set Par & 24 & $\mathrm{Y}=345,924+47,296 \mathrm{X}$ & 0,374 & 0,140 & 0,072 \\
\hline Total Set Par & 96 & $\mathrm{Y}=336,749+54,907 \mathrm{X}$ & 0,386 & 0,149 & 0,000 \\
\hline
\end{tabular}

Keterangan: Set Par $=$ Setelah Partus, $r=$ Koefisien Korelasi, $\mathrm{R}^{2}=$ Koefisien Determinasi

akan meningkatkan bobot. Hubungan antara konsumsi TDN dan bobot badan sebelum partus adalah semakin banyak konsumsi TDN maka diikuti dengan kenaikan bobot badan sapi. Bobot badan sapi pada 2 dan 1 minggu sebelum partus mengalami peningkatan. Menurut Rahman et al. (2014) saat masa kering sapi akan berhenti diperah supaya konsumsi pakan digunakan untuk pertumbuhan janin sapi dan mempersiapkan energi untuk melahirkan sehingga bobot badan meningkat.

Konsumsi energi (TDN) sapi saat kering kandang yang melebihi kebutuhan ternak akan disimpan menjadi cadangan makanan dalam bentuk bobot badan sehingga BCS sapi dapat mencukupi standar sekitar 3 - 4. Hal ini sesuai dengan pendapat Roche et al. (2010) yang menyatakan bahwa sapi kering kandang yang baik memiliki BCS sebelum melahirkan sekitar 3,5. Menurut Zachut dan Moallem (2016) BCS merupakan tolok ukur untuk mengevaluasi cadangan lemak tubuh atau makanan yang diserap dari pakan. Cadangan makanan ternak disimpan dalam bentuk lemak tubuh yang sudah ditimbun pada saat masa kering kandang akan di rombak pada saat laktasi untuk memproduksi susu apabila asupan pakan kurang, sehingga menyebabkan penurunan bobot badan ternak (Abdillah et al., 2015).

\section{Hubungan Konsumsi Protein Terhadap Bobot Badan Setelah Partus}

Hubungan konsumsi protein kasar terhadap bobot badan 4 minggu setelah partus terlihat bahwa konsumsi PK pada minggu 1 - 4 tidak berkorelasi dengan bobot masing- masing badan awal laktasi pada minggu 1 - 4 setelah partus $(P>0,05)$, namun setelah data di total selama 4 minggu, konsumsi PK setelah partus berkorelasi dengan bobot badan $(\mathrm{P}<0,05)$ dengan tingkat hubungan korelasi positif lemah $(\mathrm{r}=0,386)$ yang artinya peningkatan konsumsi protein akan diikuti oleh peningkatan bobot badan (Tabel 5). Hubungan tersebut dalam persamaan regresi $\mathrm{Y}=336,749+54,907 \mathrm{X}\left(\mathrm{R}^{2}=0,149\right)$ dan $(\mathrm{P}=0,000)$ yang artinya $14,9 \%$ variabel $\mathrm{Y}$ (bobot badan) dapat dijelaskan pleh variabel $\mathrm{X}$ (konsumsi protein). Konsumsi PK pada minggu 1 - 4 setelah partus sebesar $2,07 \mathrm{~kg} /$ hari; $2,04 \mathrm{~kg} /$ hari; $2,06 \mathrm{~kg} /$ hari dan $2,01 \mathrm{~kg} /$ hari belum dapat mencukupi kebutuhan protein sebanyak 2,15 kg/hari; 2,28kg; 2,31 kg/hari dan $2,33 \mathrm{~kg}$ /hari.

Semakin banyak konsumsi protein ternak pada awal laktasi akan diikuti dengan berkurangnya laju penurunan bobot badan, sehingga terdapat hubungan yang pasif antara keduanya. Protein pakan akan digunakan untuk mensintesis protein mikroba dalam rumen, sehingga semakin banyak mikroba rumen semakin optimal penyerapan nutrien maka semakin banyak pula nutrien yang dapat digunakan untuk hidup pokok dan produksi susu. Menurut Sunu et al. (2013) kontribusi protein yaitu memiliki kandungan senyawa asam amino yang tinggi dan dapat meningkatkan perkembangan mikroba rumen sehingga meningkatkan kecernaan serat kasar menjadi prekursor-prekursor pembentuk susu. Menurut Indriani et al. (2013) konsumsi protein dapat mempengaruhi proses sintesis protein mikroba rumen. 
Tabel 6. Uji Regresi Konsumsi TDN Terhadap Bobot Badan Setelah Partus

\begin{tabular}{lccccc}
\hline Minggu & $\mathrm{n}$ & Persamaan Regresi & $\mathrm{r}$ & $\mathrm{R}^{2}$ & P Value \\
\hline 1 Minggu Set Par & 24 & $\mathrm{Y}=6,959+0,034 \mathrm{X}$ & 0,778 & 0,605 & 0,000 \\
2 Minggu Set Par & 24 & $\mathrm{Y}=5,174+0,030 \mathrm{X}$ & 0,660 & 0,435 & 0,000 \\
3 Minggu Set Par & 24 & $\mathrm{Y}=6,591+0,034 \mathrm{X}$ & 0,764 & 0,584 & 0,000 \\
4 Minggu Set Par & 24 & $\mathrm{Y}=6,531+0,034 \mathrm{X}$ & 0,724 & 0,524 & 0,000 \\
\hline Total Set Par & 96 & $\mathrm{Y}=5,884+0,032 \mathrm{X}$ & 0,722 & 0,521 & 0,000 \\
\hline
\end{tabular}

Keterangan: Set Par $=$ Setelah Partus, $r=$ Koefisien Korelasi, $\mathrm{R}^{2}=$ Koefisien Determinasi

Konsumsi yang optimal akan meningkatkan proses fermentasi pakan sehingga produk metabolisme rumen berupa volatile fatty acid (VFA) dapat mencukupi kebutuhan pokok dan apabila energi berlebih dapat disimpan dalam cadangan tubuh sehingga bobot badan meningkat.

\section{Hubungan Konsumsi TDN Terhadap Bobot Badan Setelah Partus}

Hubungan konsumsi total digestible nutrient (TDN) terhadap bobot badan 4 minggu setelah partus terlihat bahwa konsumsi TDN sapi perah setelah partus berkorelasi terhadap bobot badan setelah partus $(\mathrm{P}<0,05)$ dengan tingkat keeratan positif moderat $(\mathrm{r}=0,674)$ yang artinya peningkatan konsumsi TDN akan diikuti oleh peningkatan bobot badan. Hubungan tersebut dalam persamaan regresi $\mathrm{Y}=5,884$ $+0,032 \mathrm{X}\left(\mathrm{R}^{2}=0,521\right)$ dan $(\mathrm{P}=0,000)$ yang artinya $52,1 \%$ variabel $\mathrm{Y}$ (bobot badan) dapat dijelaskan oleh variabel X (konsumsi TDN) (Tabel 6). Konsumsi TDN pada minggu 1 4 setelah partus sebesar $8,39 \mathrm{~kg} / \mathrm{hari} ; 8,13 \mathrm{~kg} /$ hari; $8,12 \mathrm{~kg} /$ hari dan $8,39 \mathrm{~kg} /$ hari belum dapat mencukupi kebutuhan TDN sebanyak 10,04 $\mathrm{kg} / \mathrm{hari} ; 10,37 \mathrm{~kg} ; 10,50 \mathrm{~kg} /$ hari dan $10,58 \mathrm{~kg} /$ hari. Sehingga bobot badan sapi perah mulai dari minggu ke 1 setelah partus mengalami penurunan sampai minggu ke 4 .

Semakin banyak konsumsi TDN sapi awal laktasi maka akan diikuti dengan berkurangnya laju penurunan bobot badan, sehingga terdapat hubungan yang pasif antara keduanya. Konsumsi TDN digunakan untuk mencukupi kebutuhan produksi susu dan kebutuhan pokok tubuh. Apabila konsumsi kurang maka prekursor pembentuk susu juga kurang sehingga sapi perah akan membongkar cadangan makanan atau lemak tubuh untuk mencukupi kebutuhan yang akan mengakibatkan penurunan bobot badan ternak. Jika konsumsi TDN diawal laktasi meningkat maka cadangan tubuh yang dirombak akan semakin sedikit. Menurut Suhendra et al. (2015) konsumsi TDN berasal dari pakan serat kasar yang akan digunakan sebagai bahan dasar lemak susu dan laktosa susu. Konsumsi TDN sapi laktasi yang kurang dapat menurunkan bobot badan dan produksi susu. Menurut Sunu et al. (2013) kelebihan dan kekurangan asupan nutrien diikuti dengan kenaikan dan penurunan bobot badan yang signifikan.

\section{Hubungan Konsumsi Protein Terhadap Produksi Susu}

Hubungan konsumsi protein kasar terhadap produksi susu bulan pertama awal laktasi menunjukan bahwa terdapat korelasi antara konsumsi protein terhadap produksi susu $(\mathrm{P}<0,05)$ pada minggu $1-3$ dan tidak berkorelasi $(\mathrm{P}>0,05)$ pada 4 minggu setelah partus (Tabel 7). Setelah data di jumlah selama 4 minggu, konsumsi PK setelah partus berkorelasi dengan produksi susu $(\mathrm{P}<0,05)$ dengan tingkat hubungan korelasi positif lemah $(\mathrm{r}=0,362)$ yang artinya peningkatan konsumsi protein akan diikuti oleh peningkatan produksi susu. Hubungan tersebut dalam persamaan regresi $\mathrm{Y}=5,697$ $+6,227 \mathrm{X}\left(\mathrm{R}^{2}=0,131\right)$ dan $(\mathrm{P}=0,000)$ yang artinya $13,1 \%$ variabel $\mathrm{Y}$ (produksi susu) dapat dijelaskan pleh variabel $\mathrm{X}$ (konsumsi protein). Konsumsi PK pada minggu $1-4$ 
Tabel 7. Uji Regresi Konsumsi PK Terhadap Produksi Susu

\begin{tabular}{lccccc}
\hline Minggu & $\mathrm{n}$ & Persamaan Regresi & $\mathrm{r}$ & $\mathrm{R}^{2}$ & P Value \\
\hline 1 Minggu Set Par & 24 & $\mathrm{Y}=1,826+7,404 \mathrm{X}$ & 0,451 & 0,204 & 0,027 \\
2 Minggu Set Par & 24 & $\mathrm{Y}=2,244+8,056 \mathrm{X}$ & 0,441 & 0,195 & 0,031 \\
3 Minggu Set Par & 24 & $\mathrm{Y}=2,929+7,883 \mathrm{X}$ & 0,412 & 0,170 & 0,046 \\
4 Minggu Set Par & 24 & $\mathrm{Y}=13,242+2,735 \mathrm{X}$ & 0,181 & 0,033 & 0,399 \\
\hline Setelah Partus & 96 & $\mathrm{Y}=5,697+6,227 \mathrm{X}$ & 0,362 & 0,131 & 0,000 \\
\hline
\end{tabular}

Keterangan: Set Par $=$ Setelah Partus, $r=$ Koefisien Korelasi, $\mathrm{R}^{2}=$ Koefisien Determinasi

setelah partus sebesar 2,07kg/hari; $2,04 \mathrm{~kg} /$ hari; $2,06 \mathrm{~kg} /$ hari dan $2,01 \mathrm{~kg} /$ hari belum dapat mencukupi kebutuhan protein sebanyak 2,15 $\mathrm{kg} /$ hari; $2,28 \mathrm{~kg} ; 2,31 \mathrm{~kg} /$ hari dan 2,33kg/hari.

Konsumsi protein mempunyai hubungan positif dengan produksi susu yaitu semakin banyak konsumsi protein maka akan diikuti dengan bertambahnya produksi susu. Produksi susu dipengaruhi oleh beberapa faktor seperti konsumsi protein. Konsumsi protein dari pakan nantinya akan menjadi sumber asam amino saat biosintesis protein susu. Protein susu merupakan bagian atau komponen susu dan jika produksi protein susu meningkat maka produksi susu akan ikut meningkat. Menurut Indriyani et al. (2013) produktivitas sapi perah akan optimal bila konsumsi pakan tercukupi sehingga hasil pencernaan pakan yang diserap oleh darah memiliki jumlah yang cukup untuk menghasilkan susu. Data penelitian ini menunjukan bahwa konsumsi protein belum mencukupi kebutuhan sapi sehingga berkorelasi lemah dengan produksi susu yang dihasilkan. Menurut Utomo dan Pertiwi (2010) konsumsi protein yang optimal akan diikuti dengan peningkatan kecernaan protein kasar sehingga akan meningkatkan nutrien yang akan digunakan untuk biosintesis susu.

Konsumsi protein dapat mempengaruhi produksi susu karena protein pakan akan di proses dalam rumen untuk didegradasi oleh mikroba sehingga dapat mensintesis sel tubuhnya menjadi protein mikroba, kemudian protein mikroba dicerna di abomasum dengan bantuan enzim pepsin menjadi polipeptida yang akan diubah menjadi asam-asam amino yang akan digunakan menjadi prekursor pembentuk susu. Menurut Harjanti et al. (2017) konsumsi protein yang optimal dapat meningkatkan produksi susu sapi perah laktasi karena protein pakan yang dikonsumsi akan dipecah menjadi asam-asam amino yang dapat meningkatkan produktivitas mikroba rumen untuk meningkatkan jumlah prekursor pembentuk susu sehingga susu yang dihasilkan meningkat.

\section{Respon Konsumsi Energi Terhadap Produksi Susu}

Hubungan konsumsi total digestible nutrient (TDN) terhadap produksi susu bulan pertama awal laktasi menunjukan bahwa ada korelasi antara konsumsi TDN terhadap produksi susu $(\mathrm{P}<0,05)$ dengan tingkat keeratan positif moderat $(\mathrm{r}=0,552)$ yang artinya peningkatan konsumsi TDN akan diikuti oleh peningkatan produksi susu (Tabel 8). Hubungan tersebut dalam persamaan regresi $\mathrm{Y}=4,522+0,219 \mathrm{X}\left(\mathrm{R}^{2}=0,354\right)$ dan $(\mathrm{P}$ $=0,000)$ yang artinya $35,4 \%$ variabel $\mathrm{Y}$ (produksi susu) dapat dijelaskan oleh variabel $\mathrm{X}$ (konsumsi TDN). Konsumsi TDN pada minggu $1-4$ setelah partus konsumsi TDN sebesar $8,39 \mathrm{~kg} / \mathrm{hari} ; \quad 8,13 \mathrm{~kg} / \mathrm{hari} ; \quad 8,12 \mathrm{~kg} /$ hari dan $8,39 \mathrm{~kg} /$ hari belum dapat mencukupi kebutuhan TDN sebanyak 10,04 kg/hari; $10,37 \mathrm{~kg} ; 10,50 \mathrm{~kg} /$ hari dan $10,58 \mathrm{~kg} /$ hari.

Konsumsi TDN berkorelasi dengan produksi susu tiap minggunya. Konsumsi TDN berbanding lurus dengan produksi susu. TDN pakan dipengaruhi oleh kandungan lemak, serat, protein dan abu dalam pakan sehingga konsumsi TDN mempengaruhi produksi susu karena didalamnya mengandung prekursor 
Tabel 8. Uji Regresi Konsumsi TDN Terhadap Produksi Susu

\begin{tabular}{lccccc}
\hline Minggu & $\mathrm{n}$ & Persamaan Regresi & $\mathrm{r}$ & $\mathrm{R}^{2}$ & $\mathrm{P}$ Value \\
\hline 1 Minggu Set Par & 24 & $\mathrm{Y}=4,021+0,273 \mathrm{X}$ & 0,716 & 0,512 & 0,001 \\
2 Minggu Set Par & 24 & $\mathrm{Y}=4,423+0,219 \mathrm{X}$ & 0,596 & 0,355 & 0,002 \\
3 Minggu Set Par & 24 & $\mathrm{Y}=4,460+0,213 \mathrm{X}$ & 0,623 & 0,388 & 0,001 \\
4 Minggu Set Par & 24 & $\mathrm{Y}=4,923+0,189 \mathrm{X}$ & 0,482 & 0,232 & 0,002 \\
\hline Setelah Partus & 96 & $\mathrm{Y}=4,522+0,219 \mathrm{X}$ & 0,595 & 0,354 & 0,000 \\
\hline
\end{tabular}

Keterangan: Set Par $=$ Setelah Partus, $r=$ Koefisien Korelasi, $\mathrm{R}^{2}=$ Koefisien Determinasi

pembentuk susu terutama glukosa sebagai prekusor dalam biosintesis laktosa susu. Laktosa merupakan salah satu komponen pembentuk susu yang mempunyai sifat menyerap air. Hal ini sesuai dengan pendapat Yusuf (2010) yang menyatakan bahwa glukosa dari sumber energi adalah prekursor pembuat laktosa susu, sehingga semakin banyak laktosa susu maka semakin tinggi produksinya karena semakin banyak air yang diikat. Jika laktosa meningkat maka produksi susu juga akan meningkat. Menurut Syafri et al. (2014), TDN pakan akan menghasilkan glukosa yang digunakan untuk pembentukan laktosa susu sehingga apabila konsumsi TDN tercukupi produksi susu dapat optimal. Hal ini sesuai dengan pendapat Imanto (2018) yang menyakatakan bahwa laktosa susu merupakan karbohidrat utama dalam susu yang dipengaruhi oleh karbohidrat pakan yang akan diubah menjadi glukosa kemudian disalurkan oleh darah yang akan dibawa ke ambing untuk merubah glukosa yang diserap menjadi laktosa susu yang tinggi. Menurut Indriani et al. (2013), salah satu faktor penyebab produktivitas sapi perah kurang optimal karena pemberian pakan yang belum memenuhi kebutuhan nutrien ternak baik mikro atau makro. Konsumsi TDN yang kurang dapat membuat produksi susu awal laktasi tidak optimal. Menurut Astuti et al. (2009), TDN mengandung prekursor pembentuk susu yang apabila konsumsi kurang akan mengakibatkan keseimbangan nutrient negatif berupa penurunan bobot badan karena cadangan makanan akan dibongkar untuk memenuhi kebutuhan prekursor susu.

\section{KESIMPULAN}

Konsumsi protein dan TDN memiliki hubungan positif dengan bobot badan dan produksi susu selama bulan pertama pada awal laktasi.

\section{DAFTAR PUSTAKA}

Abdillah, F., M. Hartono, dan Siswanto. 2015. Conception rate pada sapi perah laktasi di balai besar pembibitan ternak unggul dan hijauan pakan ternak Baturraden Purwokerto Jawa Tengah. J. Ilmiah Peternakan Terpadu. 3(1): 98-105.

Abdillah Z. dan P. Surjowardojo. 2018. Hubungan BCS dengan kualitas kolostrum ditinjau dari solid non fat dan berat jenis kolostrum sapi PFH. J. Ternak Tropika. 19(1): 53-59.

Anggraeni, A., Y. Fitriyani., A. Atabany., C. Sumantri, dan I. Komala. 2014. Pengaruh masa laktasi, masa kering, masa kosong dan selang beranak pada produksi susu sapi friesian-holstein di BPPT SP Cikole, Lembang. J. Ilmu Ternak dan Veteriner. 19(2): $319-325$.

Astuti, M., R. Widiati, dan Y. Y. Suranindyah. 2010. Efisiensi produksi usaha sapi perah rakyat (studi kasus pada peternak anggota koperasi usaha peternakan dan pemerahan sapi perah Kaliurang, Sleman, Yogyakarta). J. Buletin Peternakan. 34(1): 64-69.

Astuti, A., A. Agus, dan S. P. S. Budhi. 2013. 
Pengaruh penggunaan high quality feed supplement terhadap konsumsi dan kecernaan nutrien sapi perah awal laktasi. J. Peternakan. 33(2): 81-87.

Bath, D. L., F. N. Dickinson., H. A. Tucker, and R. D. Applemen. 1985. Dairy Cattle: Principles. Practices. Problems. Profits. 3rd edition. Lea and Febiger, Philadelphia.

Bilal, G., R. I. Cue, and J. F. Hayes. 2016. Genetic and phenotypic associations of type traits and body condition score with dry matter intake, milk yield, and number of breedings in first lactation Canadian holstein cows. J. Can. J. Anim. Sci. 96(1): 434-447.

Haloho, R. D., S. I. Santoso, dan S. Marzuki. 2013. Analisis profitabilitas pada usaha peternakan sapi perah di kabupaten Semarang. J. Pengembangan Humaniora. 13(1): 65 - 73.

Hanifa, A. 2018. Pengaruh pemberian ransum dengan kualitas berbeda terhadap profil darah, produksi susu dan pertambahan bobot badan sapi perah. J. Sains Peternakan. 6(1): 26 - 33.

Harjanti, W. A., D. W. Harjanti., P. Sambodho, dan S. A. B. Santoso. 2017. Pengaruh suplementasi baking soda dalam pakan terhadap urea darah dan urea susu sapi perah laktasi. J. Peternakan Indonesia. 19(2): $66-72$.

Harrison, J., R. White., R. Kincaid., E. Block., T. Jenkins, and N. St-Pierre. 2012. Effectiveness of potassium carbonate sesquihydrate to increase dietary cationanion difference in early lactation cows. J. Dairy Sci. 95(1): 3919-3925.

Holmes, C. W. dan Wilson, G. F. 1987. Milk production form pasture. Butterworths of New Zealand (Ltd), New Zealand. $162-193$.

Imanto, N. Y., D. W. Harjanti, dan R. Hartanto. 2018. Kadar glukosa darah dan laktosa susu pada sapi perah dengan pemberian suplemen herbal dan mineral proteinat. J. Riset Agribisnis dan Peternakan.
3(2): $16-21$.

Indriani, A. P., A. Muktiani, dan E. Pangestu. 2013. Konsumsi dan produksi protein susu sapi perah laktasi yang diberi suplemen temulawak (Curcuma xanthorrhiza) dan seng proteinat. J. Animal Agriculture. 2(1): $128-135$.

Laryska, N. dan T. Nurhajati. 2013. Peningkatan kadar lemak susu sapi perah dengan pemberian pakan konsentrat komersial dibandingkan dengan ampas tahu. J. Agroveteriner. 1(2): $79-87$.

Moran, J. 2005. Tropical dairy farming; feeding managemen for small hoLebar Dadaer dairy farmers in the humid tropics. Land Link Press, Melbourne.

Nugroho, K., A. Anang, dan H. Indrijani. 2015. Perbandingan model kurva produksi susu pada periode laktasi 1 dan 2 sapi friesian holstein berdasarkan catatan harian. J. Ilmu Ternak. 15(1): 30 - 36 .

Nur, K., A. Atabany., Muladno, dan A. Jayanegara. 2015. Produksi gas metan ruminansia sapi perah dengan pakan berbeda serta pengaruhnya terhadap produksi dan kualitas susu. J. Ilmu Produksi dan Teknologi Hasil Peternakan. 3(2): 65-71.

Novianti, J., B. P. Purwanto, dan A. Atabany. 2014. Efisiensi produksi susu dan kecernaan rumput gajah (Pennisetum purpureum) pada sapi perah $\mathrm{FH}$ dengan pemberian ukuran potongan yang berbeda. J. Ilmu Produksi dan Teknologi Hasil Peternakan. 2(1): 224 -230 .

NRC, National Research Council. 2001. Designingfood. Animal Product Option In The Market Place. National Research Council. Academy Press, Washington. Dc.. USA.

Piccione, G.,V. Messina., S. Marafioti., S. Casella., C. Giannetto, and F. Fazio. 2012. Changes of some haematochemical parameters in 
dairy cows during late gestation, post partum, lactation and dry periods. J. Veterinarija Ir Zootechnika. 58(80): 59-64.

Prabowo, M. D., P. Sambodho., D. W. Harjanti, dan S. A. B. Santoso. 2017. Pengaruh penambahan baking soda dalam pakan terhadap kandungan serum glutamat piruvat transaminase dan serum glutamat oksaloasetat transaminase sapi perah laktasi. JITP. 5(3): 128-132.

Putera, D. P., R. Wulansari, dan R. P. A. Lelana. 2014. Profil hematologi sapi perah FH (freisian holstein) periode kering kandang di Kunak Cibungbulang Bogor. J. Veteriner. 2(1): 1-10.

Rahman, M. T., Hermawan, dan Didin S. Tasripin. 2015. Evaluasi performa produksi susu sapi perah friesholland (FH) keturunan sapi impor. J. Student. 4(3): 1-7.

Remppis S., H. Steingass., L. Gruber, dan H. Schenkel. 2011. Effects of energy intake on performance, mobilization and retention of body tissue, and metabolic parameters in dairy cows with special regard to effects of pre-partum nutrition on lactation. J. Anim. Sci. 24(4): 540-572.

Roche, J., N. C. Friggens., J. K. Kay., M. W. Fisher., K. J. Stafford, and D. P. Berry. 2010. Body conditions score and its associations with dairy cow productivity, health and wefare. J. Dairy Science. 92(12): 769-801.

Rokhayati, U.A. 2010. Pengaruh suplementasi energi dan undegrated protein terhadap produksi susu sapi perah friesian holstein. J. Inovasi. 7(2): 33-43.

Rusadi, R. P., M. Hartono, and Siswanto. 2015. Service per conception pada sapi perah laktasi di balai besar pembibitan ternak unggul dan hijauan pakan ternak (BBPTU-HPT) Baturraden Purwokerto Jawa Tengah. J. Ilmiah Peternakan Terpadu. 3(1): 29-37.

Rusdiana dan W. K. Sejati. 2009. Upaya pengembangan agribisnis sapi perah dan peningkatan produksi susu melalui pemberdayaan koperasi susu. J. Penelitian Agro Ekonomi. 27(1): 4351.

Sari, N. F. 2017. Mengenal keragaman mikroba rumen pada perut sapi perah secara molekuler. J. Biotrends. 8(1): 5-9.

Santosa, S. A., A. T. A. Sudewo, dan A. Susanto. 2014. Penyusunan faktor koreksi produksi susu sapi perah. J. Agripet. 14(1): 1-5.

Santosa, S. I., A. Setiadi, dan R. Wulandari. 2013. Analisis potensi pengembangan usaha peternakan sapi perah dengan menggunakan paradigma agribisnis di Kecamatan Musuk Kabupaten Boyolali. J. Ilmu Peternakan. 37(2): 125-135.

Schmidt, G. H., Van Vleck, L. D. and Hutjens, M. P. 1988. Principles of Dairy Science. 2th Ed. Prentice Hall, New Jersey (US).

Staric, J. and Zadnik. 2010. Biochemical markers of bone metabolism in dairy cows with milk fever. J. Acta Veterinaria (Beograd). 60(4): 401-410.

Sulistyowati, E., I. Badarina, dan U. Santoso. 2010. Suplementasi level temulawak (Curcuma xanthorrhiza, roxb) yang berbeda dalam konsentrat pada sapi frisien holland laktasi: pengaruhnya terhadap total digestible nutrient (TDN) Ransum . J. Sains Peternakan Indonesia. 5(1): $20-26$.

Sunaryati., A. Muktiani, dan J. Achmadi. 2013. Suplementasi temulawak (Curcuma xanthoriza) dan zn proteinat terhadap konsumsi dan produksi energi susu pada sapi perah. J. Animal Agriculture. 2(1): $168-174$.

Suprayogi, A., H. Latif., Yudi, dan A. Y. Ruhyana. 2013. Peningkatan produksi susu sapi perah di peternakan rakyat melalui pemberian katuk-ipb3 sebagai aditif pakan. J. Ilmu Pertanian Indonesia. 18(3): 140-143. 
Sutardi, T. 2001. Revitalisasi peternakan sapi perah melalui penggunaan ransum berbasis limbah perkebunan dan suplementasi mineral organik. Laporan akhir RUT VIII 1. Kantor Kementrian Negara Riset dan Teknologi dan LIPI.

Suwandyastuti, S. N. O. dan E. A. Rimbawanto. 2015. Produk metabolisme rumen pada sapi perah laktasi. J. Agripet. 15(1): 16.

Syafri, A., D. W. Harjanti, dan S. A. B. Santoso. 2014. Hubungan antara konsumsi protein pakan dengan produksi. kandungan protein dan laktosa susu sapi perah di Kota Salatiga. J. Animal Agriculture. 3(3): 450-456.

Tasse, A. M dan F. A. Auza. 2014. Konsentrasi asam lemak tidak teresterifikasi (nonesterified fatty acid. NEFA). albumin. kalsium dan fosfor dalam plasma sebagai indikator status nutrisi sapi perah laktasi. J. Ilmu Ternak Tropika. 1(1): 70 - 79.

Utomo, B. dan M. D. Pertiwi. 2010. Tampilan produksi susu sapi perah yang mendapat perbaikan manajeman pemeliharaan.
J. Caraka Tani. 25(1): $21-25$.

Waldi, L., W. S. Pratama, dan F. M. Suhartati. 2017. Pengaruh penggunaan bungkil kedelai dan bungkil kelapa dalam ransum berbasis indeks sinkronisasi energi dan protein terhadap sintesis protein mikroba rumen sapi perah. J. Livestock Science and Production. 1(1): $1-12$.

Wijaya, A. K. 2016. Pengaruh penggunaan sabut buah kelapa sawit amoniasi dalam ransum sapi perah terhadap kecernaan in-vitro. J. Ilmiah Peternakan Terpadu. 4(2): 94-97.

Yusuf, R. 2010. Kandungan protein susu sapi perah Friesian Holstein akibat pemberian pakan yang mengandung tepung katuk yang berbeda. Fakultas Pertanian Universitas Mulawarman Samarinda. 6(1): 1-6

Zachut, M. and U. Moallem. 2016. consistent magnitude of post partum body weight loss within cows across lactations and the relation to reproductive erformans. J. Dairy Science. 1(1): 3143 - 3153. 